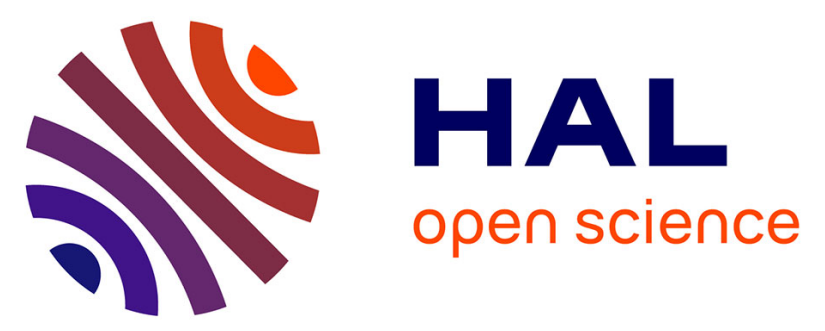

\title{
Characterisation of bacteria in ascites-reporting the potential of culture-independent, molecular analysis
}

G. B. Rogers, L. E. Russell, P. G. Preston, P. Marsh, J. E. Collins, J. Saunders, J. Sutton, D. Fine, K. D. Bruce, M. Wright

\section{- To cite this version:}

G. B. Rogers, L. E. Russell, P. G. Preston, P. Marsh, J. E. Collins, et al.. Characterisation of bacteria in ascites-reporting the potential of culture-independent, molecular analysis. European Journal of Clinical Microbiology and Infectious Diseases, 2010, 29 (5), pp.533-541. 10.1007/s10096-010-0891-5 . hal-00577971

\section{HAL Id: hal-00577971 \\ https://hal.science/hal-00577971}

Submitted on 18 Mar 2011

HAL is a multi-disciplinary open access archive for the deposit and dissemination of scientific research documents, whether they are published or not. The documents may come from teaching and research institutions in France or abroad, or from public or private research centers.
L'archive ouverte pluridisciplinaire HAL, est destinée au dépôt et à la diffusion de documents scientifiques de niveau recherche, publiés ou non, émanant des établissements d'enseignement et de recherche français ou étrangers, des laboratoires publics ou privés. 


\title{
Characterisation of bacteria in ascites-reporting the potential of culture-independent, molecular analysis
}

\author{
G. B. Rogers • L. E. Russell • P. G. Preston • P. Marsh • \\ J. E. Collins • J. Saunders • J. Sutton $\cdot$ D. Fine $\cdot$ \\ K. D. Bruce $\cdot$ M. Wright
}

Received: 4 February 2010 / Accepted: 15 February 2010/Published online: 18 March 2010

(C) Springer-Verlag 2010

\begin{abstract}
Spontaneous bacterial peritonitis (SBP) is a severe complication of liver disease. A significant proportion of patients have culture-negative ascites, despite having similar signs, symptoms and mortality to those with SBP. Therefore, empirical antibiotic treatment for infection is often started without knowledge of the causative organisms. Here, we investigated the potential of molecular techniques to provide rapid and accurate characterisation of the bacteria present in ascitic fluid. Ascites samples were obtained from 29 cirrhotic patients undergoing clinically indicated therapeutic paracentesis. Bacterial content was determined by terminal restriction fragment length polymorphism (T-RFLP) analysis, quantitative polymerase chain reaction (PCR) and $16 \mathrm{~S}$ ribosomal clone sequence analysis. Bacterial signal was detected in all samples,
\end{abstract}

G. B. Rogers $(\bowtie) \cdot$ L. E. Russell $\cdot$ K. D. Bruce

Molecular Microbiology Research Group, PSD,

King's College London,

London, UK

e-mail: geraint.rogers@kcl.ac.uk

P. G. Preston $\cdot$ D. Fine $\cdot$ M. Wright

Specialist Medicine Group, Southampton General Hospital,

Southampton, UK

P. Marsh · J. Sutton

Health Protection Agency South East,

Southampton General Hospital,

Tremona Road,

Southampton SO16 6YD, UK

J. E. Collins $\cdot$ J. Saunders

School of Medicine, University of Southampton,

Southampton General Hospital,

Tremona Road,

Southampton SO16 6YD, UK compared to three out of ten using standard methods. Bacterial loads ranged from $5.5 \times 10^{2}$ to $5.4 \times 10^{7} \mathrm{cfu} / \mathrm{ml}$, with a mean value of $1.9 \times 10^{6} \mathrm{cfu} / \mathrm{ml}$ (standard deviation \pm $\left.9.6 \times 10^{6} \mathrm{cfu} / \mathrm{ml}\right)$. In all but one instance, bacterial species identified by culture were also confirmed by molecular analyses. Preliminary data presented here suggests that culture-independent, molecular analyses could provide rapid characterisation of the bacterial content of ascites fluid, providing a basis for the investigation of SBP development and allowing early and targeted antibiotic intervention.

\section{Introduction}

Spontaneous bacterial peritonitis (SBP) is a common and severe complication in patients with cirrhosis and ascites [1], occurring in $10-25 \%$ of patients, with an in-hospital mortality rate ranging from 20 to $40 \%$ [2-5]. The development of SBP requires bacteria to be present in the ascitic fluid, with a likely preclinical phase prior to the development of symptoms. Improving the ability to rapidly characterise the bacterial content of ascitic fluid would have major clinical benefits. Early bacterial detection and characterisation would allow targeted intervention to prevent the development of SBP, or where peritonitis is already present, treatment with the most appropriate therapy. Further, access to such data would allow the effective monitoring of treatment efficacy.

Culture-based analysis of ascitic fluid has shown that a wide range of bacterial species can be isolated. Common Gram-negative bacteria such as Escherichia coli and other coliforms such as Klebsiella spp. have been reported to be causative agents in at least $50 \%$ of cases [6-10]. Other 
causative organisms reported have included pneumococci, streptococci and miscellaneous Gram-positive and other Gram-negative organisms [6-10].

Despite this, even where the most modern practice is applied, ascites fluid culture is negative in approximately $20 \%$ of patients with clinical manifestations suggestive of SBP, including elevated ascites polymorphonuclear leukocyte (PMN) counts [11]. Where there is evidence of infection, delaying treatment until the ascitic fluid culture grows bacteria may result in the death of the patient from overwhelming infection [11]. Therefore, empirical antibiotic treatment for SBP is initiated when objective evidence of a local inflammatory reaction is present, i.e. an elevated ascites PMN count $\left(\geq 250\right.$ cells $\left./ \mathrm{mm}^{3}\right)$, without prior knowledge of the causative organisms or their antibiotic susceptibility [12]. Patients with a PMN count $\geq 250$ cells/ $\mathrm{mm}^{3}$ but whose ascites is culture-negative (sometimes referred to as culture-negative neutrocytic ascites [13]) have similar signs, symptoms and mortality as patients with SBP [12-15], suggesting the presence of bacterial species that are refractory to culture under standard conditions or that are present at relatively low concentrations [12].

The limitations of culture-based identification of bacteria in clinical samples is increasingly well recognised in other contexts $[16,17]$. The reporting of false-negative results, where no causative agent(s) are observed using traditional culture-based diagnostic microbiological analysis of samples, have been shown to occur in many infective scenarios [18]. In contrast to culture-based methodologies, the rapid and accurate identification of bacteria in clinical samples using molecular, culture-independent approaches has led to the rapid proliferation of the use of such strategies $[19,20]$. Their particular strength is in their ability to detect bacterial species, regardless of whether these species can be grown readily in vitro. In the study presented here, we investigated the potential of three culture-independent strategies to characterise the bacterial content of ascites fluid. These strategies included the determination of overall bacterial diversity present by terminal restriction fragment length polymorphism (T-RFLP) profiling, the confirmation of species identities through $16 \mathrm{~S}$ ribosomal gene clone sequence analysis and the determination of total bacterial load through quantitative polymerase chain reaction (PCR). These techniques have been shown in other contexts to provide data on both the size and nature of the bacterial load present within clinical samples $[16,18,20]$. Here, we report their first application to the analysis of ascitic fluid. In doing so, we hypothesised that a range of different bacterial species would be present in these samples that were not habitually detected by conventional culture-based assessment. In this initial study, we demonstrate the feasibility of these approaches to study bacteria without cultivation from ascitic fluid. We also discuss the potential that such strategies hold for future investigations into the aetiology and treatment of SBP.

\section{Materials and methods}

DNA extraction from ascites samples

Samples were obtained from 29 cirrhotic patients undergoing clinically indicated therapeutic paracentesis for tense ascites at Southampton General Hospital, Hampshire, UK, under full ethical approval (see Table 1). Approximately $20 \mathrm{ml}$ of ascites were centrifuged at $6,000 \mathrm{~g}$ for $10 \mathrm{~min}$ in $50 \mathrm{ml}$ Oak Ridge tubes (Nalgene Labware), with the resulting pellets resuspended in $0.5 \mathrm{ml}$ of sterile phosphate-buffered saline (PBS) and stored at $-80^{\circ} \mathrm{C}$.

DNA extraction from ascites cell pellets was performed using the QIAamp DNA Mini Kit (Qiagen, Crawley, UK) in accordance with the manufacturer's instructions. Cell pellets were resuspended in $200 \mu 1$ PBS for extraction and eluted in a volume of $50 \mu \mathrm{l}$ of sterile distilled water. Extracted DNA was verified by TAE agarose gel electrophoresis as described below.

PCR amplification, restriction endonuclease digestion and T-RFLP profiling

PCR amplification, restriction endonuclease digestion and T-RFLP profiling were performed as described previously [21].

\section{Quantitative PCR}

All quantitative PCR analyses were performed in triplicate. The total bacterial load was determined using TaqMan assay, which amplified a 466-bp fragment (as determined for $E$. coli) of the 16S ribosomal RNA gene, using the forward primer EubF (5'-TCCTACGGGAGG CAGCAGT-3'), the reverse primer EubR (5'-GGACTAC CAGGGTATCTAATCCTGTT-3') and the probe EubPR (5'-FAM-CGTATTACCGCGGCTGCTGGCAC-TAMRA$\left.3^{\prime}\right)$, as described previously by Nadkarni et al. [22]. Quantitative PCR assays were performed using the RotorGene 6000 (Qiagen, Crawley, UK). All primers and probes were manufactured by Integrated DNA Technologies, Leuven, Belgium. Bacterial primers and probe were used at a concentration of $100 \mathrm{nM}$ each and the probe at a concentration of $250 \mathrm{nM}$.

Each reaction contained $1 \times$ LightCycler 480 Probes Master mix (Roche, Welwyn Garden City, UK) and $4 \mu \mathrm{L}$ of template, the total reaction volume being $20 \mu \mathrm{L}$. Quantitative PCR was performed in $50-\mu \mathrm{L}$ plastic capillaries 
(Qiagen, Crawley, UK) as follows: $95^{\circ} \mathrm{C}$ for $5 \mathrm{~min}$, followed by 45 thermal cycles, with each cycle comprising a step at $95^{\circ} \mathrm{C}$ for $10 \mathrm{~s}$ and a step at $60^{\circ} \mathrm{C}$ for $45 \mathrm{~s}$ with fluorescence acquisition (at $510 \mathrm{~nm}$ ) at the end of each 45 -s $60^{\circ} \mathrm{C}$ step. A positive was read as a fluorescence curve at $510 \mathrm{~nm}$ giving a cycle threshold $(\mathrm{CT})$ value of $<35$.

Load per $\mathrm{ml}$ was determined by comparison with standard curves generated from bacterial isolates. A methicillin-sensitive Staphylococcus aureus (MSSA) standard curve was used for bacterial load estimations. The bacterial assay was also tested against the other standard curves (Pseudomonas aeruginosa, Streptococcus pyogenes and E. coli) to test for any variation in load estimation between different species with different $16 \mathrm{~S}$ ribosomal RNA gene copy numbers. Separate nutrient broth cultures of MSSA (ATCC 29213), P. aeruginosa (NCTC 12934/ATCC 27853), S. pyogenes (ATCC 19615) and E. coli (NCTC 12241/ATCC 25922) isolates were incubated at $37^{\circ} \mathrm{C}$ for $16 \mathrm{~h}$, and the cfu/ml values were estimated by incubation of dilutions $(n=4)$ on Columbia blood agar at $37^{\circ}$ for $24 \mathrm{~h}$, followed by colony counts. DNA was extracted from ten-fold dilutions of these broth cultures in the same way as for the sputum and quantitative PCR was carried out as above on the DNA extracts. "No template" controls were included in all PCR reactions to serve as a reporter for the bacterial contamination of PCR reagents.

\section{Clone sequence analysis}

16S rRNA gene clone sequence analysis was performed as described previously [21]. Sequences obtained in the present study were stored under accession numbers FN554266 to FN554372.

\section{Results}

Culture-based diagnostic microbiology

Routine diagnostic microbiology was performed on samples from all patients within this study. All samples collected in universal containers were found to be culturenegative when analysed by standard ascites microscopy, culture and sensitivity (MC\&S). Samples from a subset of patients (Patients 1-5, 8 and 10-29) were also inoculated into blood culture bottles prior to transfer to the laboratory. Of these, all but three were again culture-negative; Enterococcus faecalis, Alcaligenes xylosoxidans and a Gram-positive bacillus were isolated from Patient 1, Streptococcus mitis from Patient 3, and a Gram-negative bacillus from Patient 8 . These data are summarised in Table 1.
Culture-independent analysis: (i) determination of bacterial load using quantitative PCR

Quantitative PCR was used to quantify the bacterial load in each of the ascites samples and was performed in triplicate in each case. Bacterial loads ranged from $5.5 \times 10^{2}$ to $5.4 \times$ $10^{7} \mathrm{cfu} / \mathrm{ml}$, with a mean value of $1.9 \times 10^{6} \mathrm{cfu} / \mathrm{ml}$ (standard deviation $\pm 9.6 \times 10^{6} \mathrm{cfu} / \mathrm{ml}$ ). Bacterial loads for each individual sample are shown in Table 1 .

\section{Culture-independent analysis: (ii) T-RFLP}

The number of bands resolved in T-RFLP profiles generated from the ten ascites samples ranged from 0 to 22 , with a mean of $8.5( \pm 5.1)$. A total of 79 different T-RF band lengths were detected in the sample set as a whole. The percentage values for the total signal detected for each T-RF band length in each sample profile are shown in Fig. 1.

No T-RF band lengths detected was common to all of the samples analysed. However, the most commonly detected T-RF band was 155 bases, corresponding with that derived from $P$. aeruginosa, and was resolved in 24 of the 29 samples. A T-RF band of 209 bases was resolved in 12 samples, corresponding to that derived from a range of bacterial species, including Actinomyces spp., Burkholderia spp., Chromohalobacter spp., Halomonas spp., Kingella spp., Nitrosomonas spp., Pseudomonas spp., Psychrobacter spp., Ralstonia spp., Simonsiella spp. and Stenotrophomonas spp. T-RF bands of 241 bases and 377 bases were each resolved in 9 of the 24 samples, corresponding with those predicted for Bacillus spp. and Clostridium spp., and for Clostridium spp., Eubacterium spp., Vibrio spp., Lachnospira spp. and Syntrophomonas spp., respectively. A T-RF band of 82 bases, corresponding with the predicted band length for both Deinococcus spp. and Sphingomonas spp., was resolved in 8 of the 24 samples. In addition, there were two T-RF band lengths resolved in seven of the samples, four resolved in six samples, seven resolved in five samples, six resolved in four samples, nine resolved in three samples and 14 resolved in two samples.

\section{Culture-independent analysis: (iii) 16S rRNA gene} sequences

Clone sequence analysis was performed on three of the ten samples selected at random (samples from Patients 6, 7 and 8 ). This process identified 24 separate bacterial species or phylogenetic groups in the 107 cloned sequences analysed (Table 2). In Patient 6, only one species, E. faecium, was identified. In contrast, the clone sequences derived from the samples obtained from Patients 7 and 8 were 


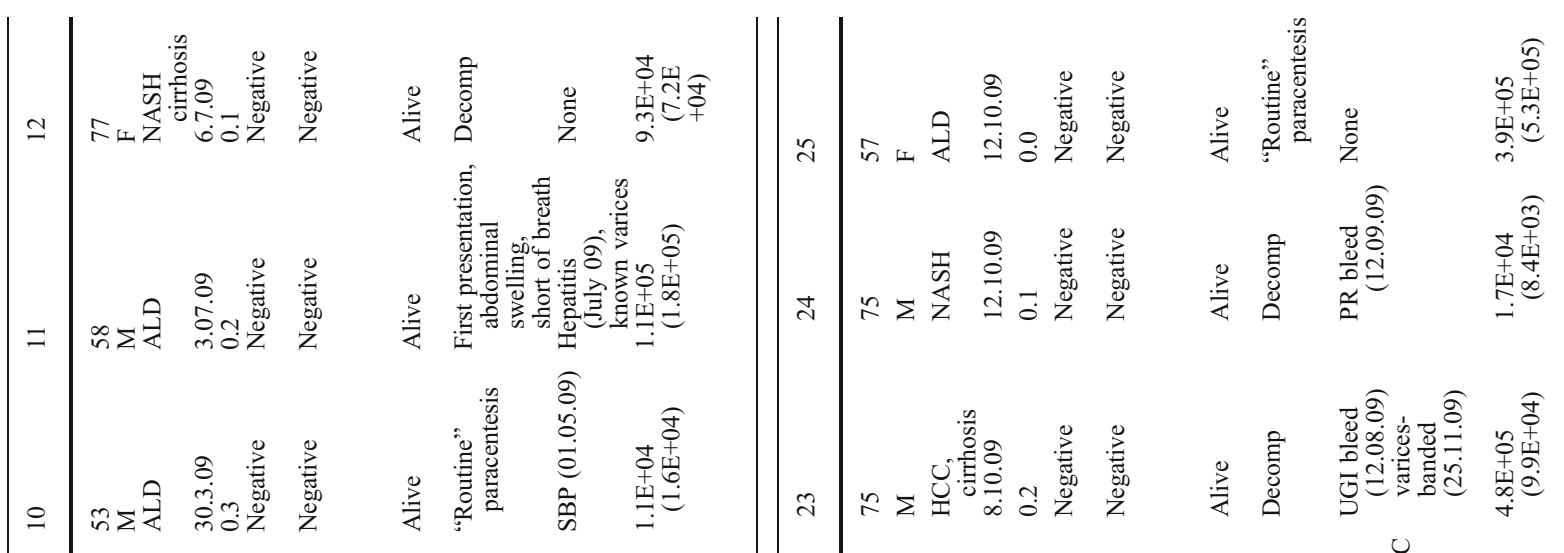

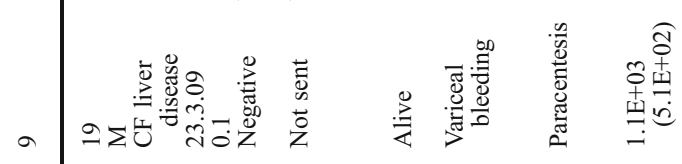

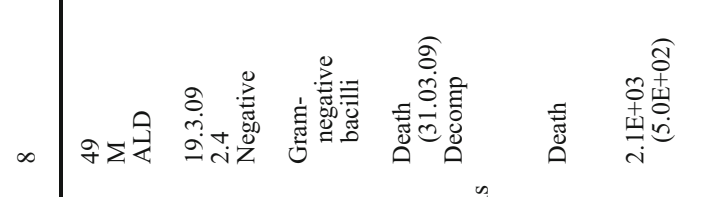

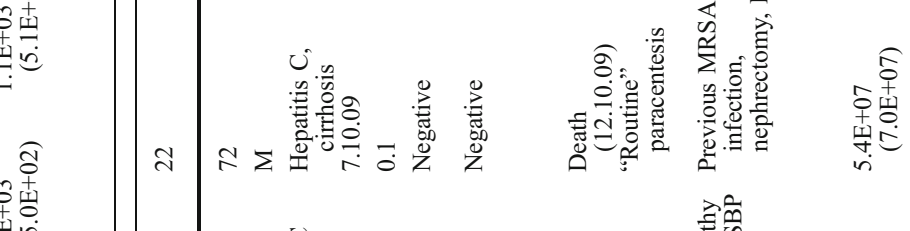

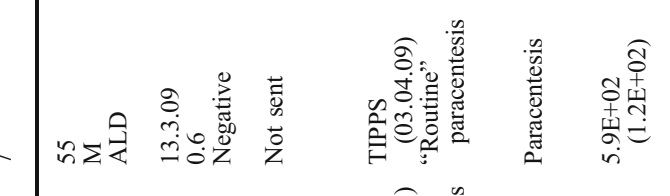

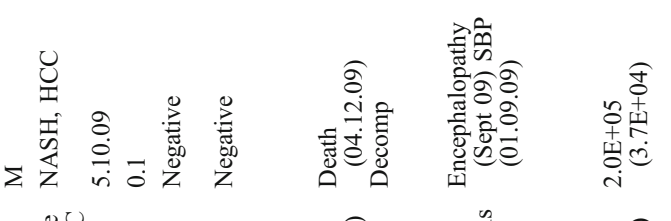

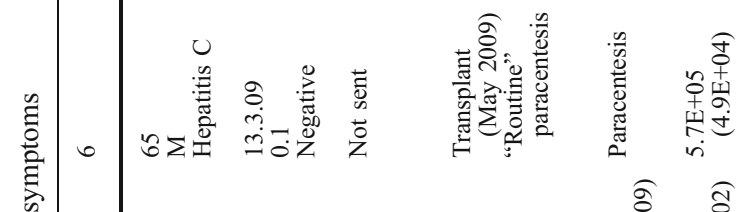

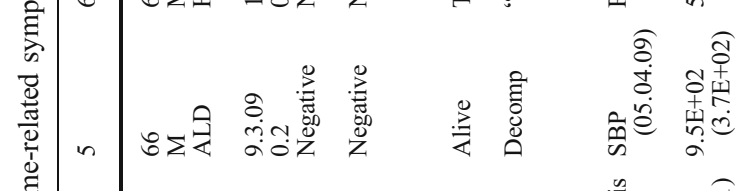




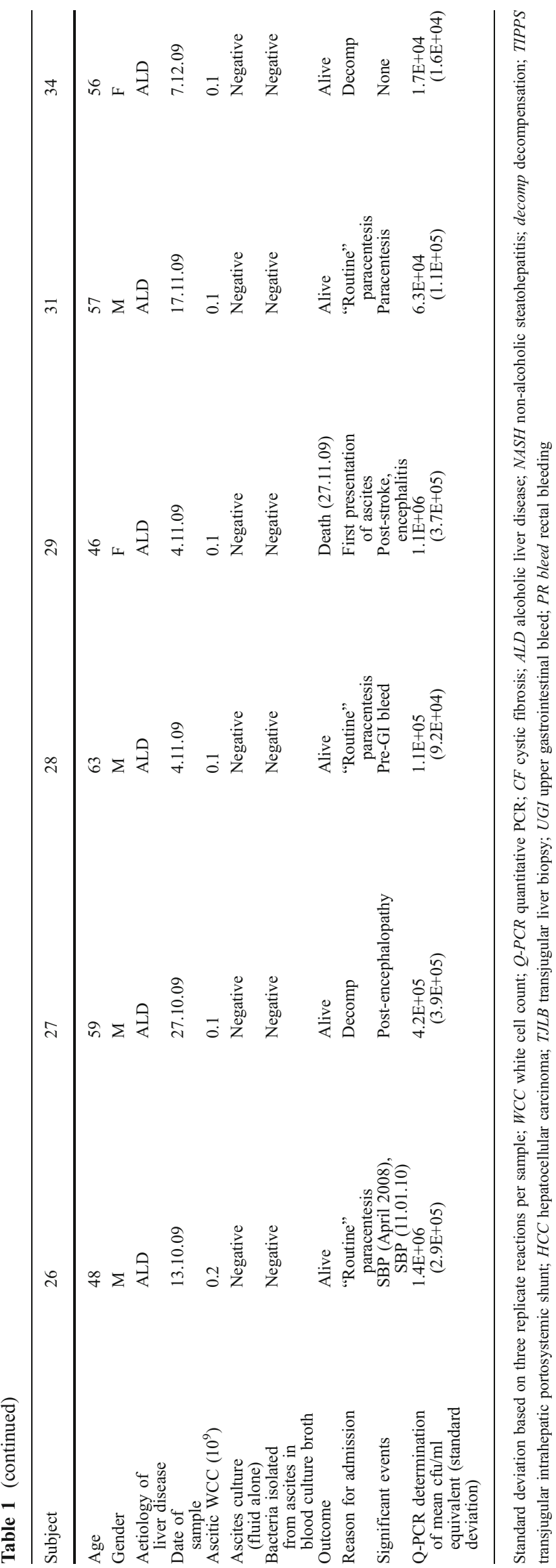

phylogenetically diverse, with the genera Acinetobacter, Bacillus, Burkholderia, Caulobacter, Curvibacter, Escherichia, Janthinobacterium, Leifsonia, Lysinibacillus, Novosphingobium, Prevotella, Propionibacterium, Proteus, Pseudomonas, Sphingomonas, Staphylococcus and Streptococcus all represented.

\section{Comparison of culture and T-RFLP data}

As above, bacteria were isolated by culture from three of the samples; E. faecalis, A. xylosoxidans and an unidentified Gram-positive bacillus from sample 1, S. mitis from sample 3 and an unidentified Gram-positive bacillus from sample 8. A band corresponding to A. xylosoxidans (571 bases) was detected in sample 1 and represented $0.7 \%$ of the total profile signal, but no band corresponding to E. faecalis (218 bases) was detected in this sample. A band corresponding to S. mitis (574 bases) was detected in sample 3 and represented $1.08=1.1 \%$ of the total profile signal. In both samples 1 and 8 , T-RF bands were resolved that correspond to the band length predicted for a number of Gram-positive bacilli, including those predicted for both Bacillus and Streptococcus spp., were detected. However, due to the lack of specificity of culturebased characterisation, it was not possible to determine which bands might correspond to the reported culture isolate.

Comparison of 16S rRNA gene sequence libraries and T-RFLP data

In the case of Patient 6 , the only species to be identified through clone sequence analysis, E. faecium, produced a T-RF band of 218 bases in length. A 218-base T-RF band was the second most intense band in the T-RFLP profile generated from this sample $(23.9 \%$ of the total profile signal).

In the case of Patient 7, the phylogenetic groups most highly represented in the clone sequences were members of the genus Acinetobacter (27\% of clones), members of the genus Bacillus (11\% of clones) and members of the genus Lysinibacillus (11\% of clones). T-RF bands consistent with all of these groups were detected in the corresponding $\mathrm{T}$ RFLP profile, and represented $15.3,4.8$ and $3.5 \%$ of the total T-RF profile signal, respectively. In the case of Patient 8 , the phylogenetic groups most highly represented in the clone sequences were $S$. aureus (33\% of clones), P. acnes (17\% of clones) and members of the genus Acinetobacter (14\% of clones). T-RF bands consistent with $S$. aureus were detected in the corresponding T-RFLP profile, and represented $26.3 \%$ of the total T-RF profile signal. However, T$\mathrm{RF}$ bands corresponding to $P$. acnes and members of the genus Acinetobacter were not resolved. 

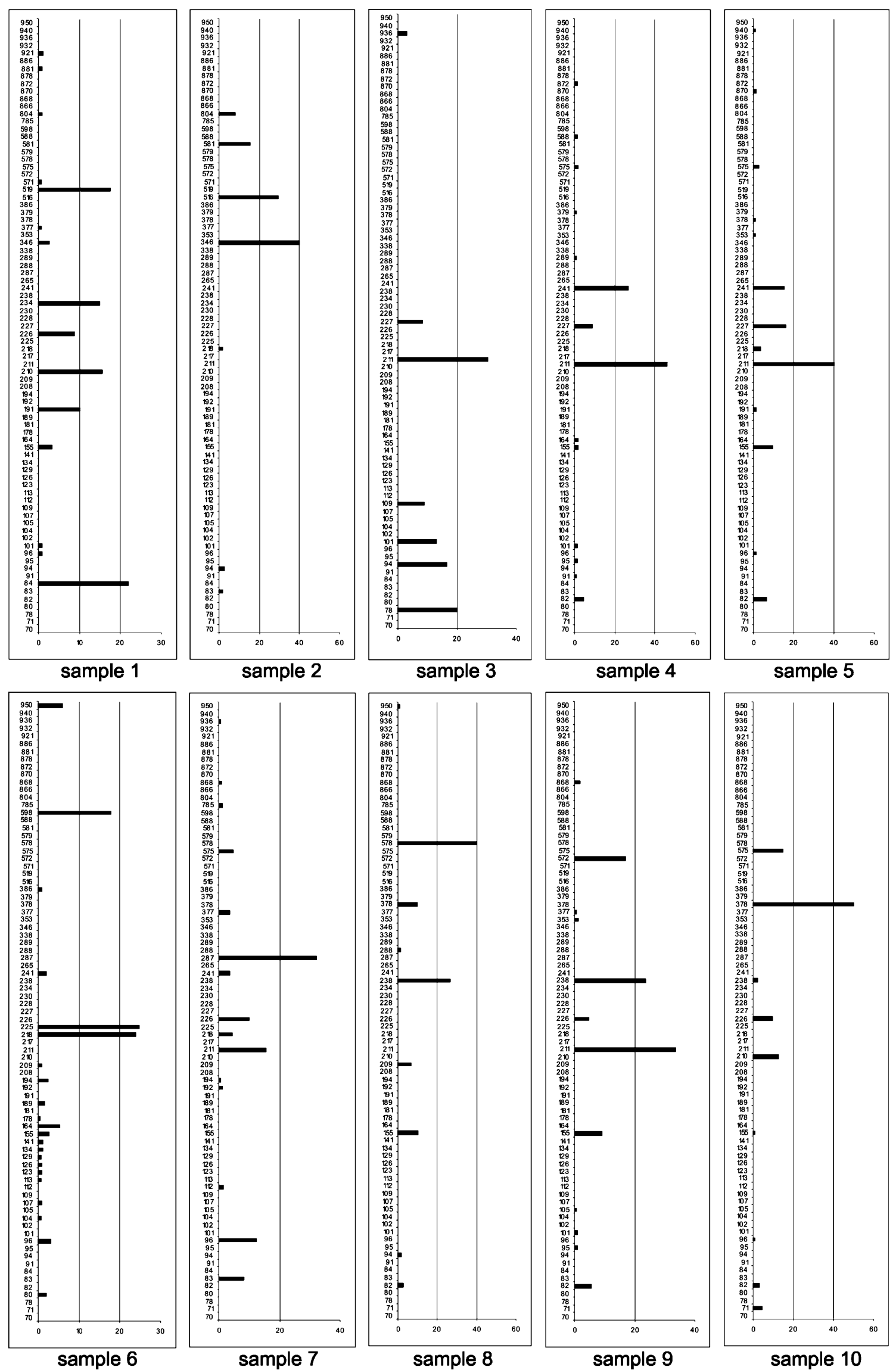
Fig. 1 Signal distribution in terminal restriction fragment length polymorphism (T-RFLP) profiles generated from each of ascites samples. The horizontal bars show the percentage of the total $\mathrm{T}$ RFLP signal represented by each of the T-RFLP bands detected in the profile. T-RF band lengths (bases) are shown on the vertical axis

\section{Discussion}

The results presented here represent a significant development in this important clinical field. Ascitic fluid state should no longer be considered as either sterile or infected, but instead to be part of a spectrum that includes both polymicrobial colonisation and clinically evident infection.

Despite improvements in the analysis of ascites fluid [7], a significant proportion of patients who have clinical manifestations suggestive of SBP, including elevated levels of ascites PMN, have culture-negative ascites. This results in empirical antibiotic treatment for SBP often being initiated without the identification of infective agents,

Table 2 Incidence of bacterial species present in 16S rRNA genes cloned from polymerase chain reaction (PCR) products amplified from DNA extracted directly from three clinical samples. The numbers represent the number of cloned sequences derived from each of the bacterial taxa listed

\begin{tabular}{|c|c|c|c|}
\hline Bacterial species & Patient 6 & Patient 7 & Patient 8 \\
\hline Acinetobacter junii & & 1 & \\
\hline Acinetobacter sp. & & 9 & 5 \\
\hline Bacillus cereus/subtilis/thuringiensis & & 4 & 2 \\
\hline Burkholderia spp. & & & 2 \\
\hline Caulobacter leidyi & & 1 & \\
\hline Curvibacter lanceolatus & & 1 & \\
\hline Enterococcus faecium & 34 & & \\
\hline Escherichia coli & & 2 & 1 \\
\hline Janthinobacterium spp. & & 1 & \\
\hline Leifsonia xyli & & 1 & \\
\hline Lysinibacillus sphaericus/fusiformis & & 4 & \\
\hline Novosphingobium spp. & & 1 & 1 \\
\hline Prevotella pallens & & 1 & \\
\hline Propionibacterium acnes & & 1 & 6 \\
\hline Proteus mirabilis & & & 1 \\
\hline Pseudomonas aeruginosa & & 1 & \\
\hline Pseudomonas fluorescens & & 2 & 1 \\
\hline Pseudomonas spp. & & & 1 \\
\hline Pseudomonas veronii & & 2 & \\
\hline Sphingomonas spp. & & 2 & 3 \\
\hline Staphylococcus aureus & & 1 & 12 \\
\hline Streptococcus mitis & & & 1 \\
\hline Streptococcus pseudopneumoniae & & 1 & \\
\hline Uncultured Firmicute & & 1 & \\
\hline Total clones & 34 & 37 & 36 \\
\hline
\end{tabular}

greatly hampering the selection of the most appropriate treatment strategy. This problem is not limited to the analysis of ascites, and the inability of traditional bacteriological culture-based diagnostics to accurately characterise the microbial content of clinical samples is well recognised [16]. The inadequacy of culture-based assays to provide sufficiently rapid, accurate and comprehensive data on which to base clinical decisions has led to the development and use of culture-independent, molecular strategies in an increasing number of clinical contexts. The rationale for taking a culture-independent approach in this study was underpinned by earlier studies that have shown bacterial DNA in fluid from approximately $40 \%$ of cirrhosis patients with culture-negative, non-neutrocytic ascites [23, 24]. Moreover, the presence of bacterial DNA has recently been shown to be associated with an increased risk of developing SBP [25]. Here, we describe the first application of molecular, culture-independent techniques to the characterisation of bacteria in ascitic fluid samples.

Culture-independent quantitative PCR was used here to determine the total bacterial load in the samples analysed. This process employs PCR primers specific and conserved to regions of a gene across all different types of bacterial cells. Despite the high proportion of culture-negative samples, bacteria were detected in 28 of the 29 samples, with an average load equivalent to ca. $1.9 \times 10^{6} \mathrm{cfu} / \mathrm{ml}$, confirming the sensitivity of this molecular strategy, and again underlining differences between culture-based and culture-independent approaches. It should, however, be noted here that, in some instances, the bacterial loads detected were low. Therefore, were smaller volumes of ascites fluid available for analysis, the detection of bacteria may not have been achieved. This underlines the importance of basing molecular analyses such as these on an appropriate sampling system. A further consideration is the impact that differences in ribosomal operon number and growth rates between the bacteria present in the sample and those used to generate quantitative PCR calibration curves may have [22]. No significant difference in PCR amplification efficiency were identified in the calibration curves generated from $S$. aureus, S. pyogenes, $P$. aeruginosa or $E$. coli; however, the use of $S$. pyogenes, $P$. aeruginosa or $E$. coli rather than $S$. aureus led to $\log ^{10}$ changes in mean cfu $/ \mathrm{ml}$ values of $+1.10,+0.79$ and -1.78 respectively. Whilst it was felt that the values derived from comparisons with the $S$. aureus curve represented a compromise between these values, it should be noted that such differences between cultures used to calibrate quantitative-based, broad-spectrum, bacterial PCR can significantly affect the absolute bacterial load values obtained, which should, therefore, be treated with caution.

The detection of bacterial species through cultureindependent means that is presented here is all the more 
significant given that these patients were undergoing paracentesis for volume-related symptoms rather than because of a suspicion of sepsis. In the absence of sepsisrelated symptoms and an elevated white cell count (WCC), the ascites has been presumed for practical purposes to be sterile. Our results demonstrate that this assumption is false. Here, we propose that it is more likely that a continuum exists from low-level colonisation in the absence of a neutrophil response or systemic or local infection, through to clinically significant and severe SBP, which develops in only a subset of individuals. The current use of the ascitic WCC to base clinical decisions with help from occasional positive cultures may, therefore, be a vast oversimplification, with the data from this initial study suggesting that this needs to be revisited subsequently. Further, whilst not all of the bacteria that are present in ascites fluid will be clinically significant, the presence of these species should not ignored. Research based on the approaches used here will enable an iterative process that will, in the longer term, establish which species, at what levels and in what circumstances, are of clinical importance.

Culture-independent T-RFLP profiling analysis was used here primarily to determine the diversity and number of bacterial species present. This approach, which has been used extensively to characterise bacteria in samples from a range of clinical contexts [21, 26, 27], has been shown to be accurate and reproducible. As with any analytical technique, T-RFLP is subject to constraints imposed by detection thresholds, with this approach, as such, resolving the numerically dominant bacterial species. Despite this, the profiles generated from the ascites samples analysed here showed high levels of diversity, with around eight separate species detected per sample. From this, it is particularly important for future studies to determine whether the progression towards peritonitis is typified by an increase in all of the species present or whether certain species best adapted to growing in the peritoneal space expand and become numerically dominant.

Culture-independent $16 \mathrm{~S}$ ribosomal RNA gene clone sequence analysis is widely regarded as a gold standard for the identification to the species level of bacteria, and was used here to determine the identities of the bacteria present in a subset of samples, resolving 24 separate bacterial species in three samples. By providing detailed and accurate data regarding the identities of species present in ascitic fluid, culture-independent profiling strategies have the potential to distinguish between bacterial peritonitis that has developed spontaneously through the translocation of bacteria from the gut, and that which has developed through the introduction of an indwelling device (secondary bacterial peritonitis). This is illustrated in the clone sequence data presented here-two of the samples analysed contain species commonly found in the gut microbiota, whilst the third is composed mainly of species commonly found on the surface of the skin.

The ability of culture-independent profiling strategies to identify bacterial species not detected by culture was also highlighted here, with the identification of species in four genera that have not previously been reported in the context of peritonitis: Janthinobacterium, Leifsonia, Lysinibacillus and Curvibacter. This finding becomes more interesting, given the relatively limited use of clone sequence analysis in this study. Further, one genus identified in this way, Caulobacter, has previously been reported only once in the context of human infection, isolated, perhaps tellingly, from the dialysis fluid of a patient undergoing peritoneal dialysis [28].

SBP develops in a significant proportion of individuals shown to have bacteria in their ascites [29], suggesting the presence of bacteria prior to the development of an elevated PMN count or other evidence of local or systemic infection, which may represent an intermediate stage on the way to infection. However, the development of a rapid, sensitive and accurate method to detect and characterise bacteria in ascites would provide an opportunity to make an appropriate intervention before an infection has been established. Further, where SBP does develop but antibiotic therapy is not effective, the mortality rate is very high, even when antibiotic treatment is appropriately modified [12, 30, 31]. Therefore, assessing the course of the infection is important to recognise treatment failure as early as possible. We suggest that further investigation is now required to determine the potential of molecular profiling strategies to characterise the bacteria present in ascites fluid and provide insight into the development of SPB.

\section{References}

1. Sort P, Navasa M, Arroyo V, Aldeguer X, Planas R, Ruiz-delArbol L, Castells L, Vargas V, Soriano G, Guevara M, Ginès P, Rodés J (1999) Effect of intravenous albumin on renal impairment and mortality in patients with cirrhosis and spontaneous bacterial peritonitis. N Engl J Med 341:403-409

2. Guarner C, Solà R, Soriano G, Andreu M, Novella MT, Vila MC, Sàbat M, Coll S, Ortiz J, Gómez C, Balanzó J (1999) Risk of a first community-acquired spontaneous bacterial peritonitis in cirrhotics with low ascitic fluid protein levels. Gastroenterology 117:414-419

3. Thuluvath PJ, Morss S, Thompson R (2001) Spontaneous bacterial peritonitis - in-hospital mortality, predictors of survival, and health care costs from 1988 to 1998. Am J Gastroenterol 96:1232-1236

4. Llovet JM, Moitinho E, Sala M, Bataller R, Rodríguez-Iglesias P, Castells A, Fernández J, Planas R, Navasa M, Bruix J, Rodés J (2000) Prevalence and prognostic value of hepatocellular carcinoma in cirrhotic patients presenting with spontaneous bacterial peritonitis. J Hepatol 33:423-429

5. Park YH, Lee HC, Song HG, Jung S, Ryu SH, Shin JW, Chung YH, Lee YS, Suh DJ (2003) Recent increase in antibiotic-resistant microorganisms in patients with spontaneous bacterial peritonitis 
adversely affects the clinical outcome in Korea. J Gastroenterol Hepatol 18:927-933

6. Cheong HS, Kang CI, Lee JA, Moon SY, Joung MK, Chung DR, Koh KC, Lee NY, Song JH, Peck KR (2009) Clinical significance and outcome of nosocomial acquisition of spontaneous bacterial peritonitis in patients with liver cirrhosis. Clin Infect Dis 48:1230 1236

7. Runyon BA (2003) The evolution of ascitic fluid analysis in the diagnosis of spontaneous bacterial peritonitis. Am J Gastroenterol 98:1675-1677

8. Koulaouzidis A, Bhat S, Karagiannidis A, Tan WC, Linaker BD (2007) Spontaneous bacterial peritonitis. Postgrad Med J 83:379383

9. García-Tsao G (1992) Spontaneous bacterial peritonitis. Gastroenterol Clin North Am 21:257-275

10. Arroyo V, Jiménez W (2000) Complications of cirrhosis. II. Renal and circulatory dysfunction. Lights and shadows in an important clinical problem. J Hepatol 32:157-170

11. Runyon BA; AASLD Practice Guidelines Committee (2009) Management of adult patients with ascites due to cirrhosis: an update. Hepatology 49:2087-2107

12. Rimola A, García-Tsao G, Navasa M, Piddock LJ, Planas R, Bernard B, Inadomi JM (2000) Diagnosis, treatment and prophylaxis of spontaneous bacterial peritonitis: a consensus document. International Ascites Club. J Hepatol 32:142-153

13. Runyon BA, Hoefs JC (1984) Culture-negative neutrocytic ascites: a variant of spontaneous bacterial peritonitis. Hepatology 4:1209-1211

14. Terg R, Levi D, Lopez P, Rafaelli C, Rojter S, Abecasis R, Villamil F, Aziz H, Podesta A (1992) Analysis of clinical course and prognosis of culture-positive spontaneous bacterial peritonitis and neutrocytic ascites. Evidence of the same disease. Dig Dis Sci 37:1499-1504

15. Pelletier G, Salmon D, Ink O, Hannoun S, Attali P, Buffet C, Etienne JP (1990) Culture-negative neutrocytic ascites: a less severe variant of spontaneous bacterial peritonitis. J Hepatol 10:327-331

16. Rogers GB, Carroll MP, Bruce KD (2009) Studying bacterial infections through culture-independent approaches. J Med Microbiol 58:1401-1418

17. Rogers GB, Daniels TWV, Tuck A, Carroll MP, Connett GJ, David GJ, Bruce KD (2009) Studying bacteria in respiratory specimens by using conventional and molecular microbiological approaches. BMC Pulm Med 9:14

18. Harris KA, Hartley JC (2003) Development of broad-range 16S rDNA PCR for use in the routine diagnostic clinical microbiology service. J Med Microbiol 52:685-691

19. Whelen AC, Persing DH (1996) The role of nucleic acid amplification and detection in the clinical microbiology laboratory. Annu Rev Microbiol 50:349-373

20. Espy MJ, Uhl JR, Sloan LM, Buckwalter SP, Jones MF, Vetter EA, Yao JD, Wengenack NL, Rosenblatt JE, Cockerill FR 3rd,
Smith TF (2006) Real-time PCR in clinical microbiology: applications for routine laboratory testing. Clin Microbiol Rev 19:165-256

21. Rogers GB, Carroll MP, Serisier DJ, Hockey PM, Jones G, Bruce KD (2004) Characterization of bacterial community diversity in cystic fibrosis lung infections by use of 16 s ribosomal DNA terminal restriction fragment length polymorphism profiling. J Clin Microbiol 42:5176-5183

22. Nadkarni MA, Martin FE, Jacques NA, Hunter N (2002) Determination of bacterial load by real-time PCR using a broad-range (universal) probe and primers set. Microbiology 148:257-266

23. Such J, Francés R, Muñoz C, Zapater P, Casellas JA, Cifuentes A, Rodríguez-Valera F, Pascual S, Sola-Vera J, Carnicer F, Uceda F, Palazón JM, Pérez-Mateo M (2002) Detection and identification of bacterial DNA in patients with cirrhosis and culture-negative, nonneutrocytic ascites. Hepatology 36:135-141

24. Francés R, Benlloch S, Zapater P, González JM, Lozano B, Muñoz C, Pascual S, Casellas JA, Uceda F, Palazón JM, Carnicer F, Pérez-Mateo M, Such J (2004) A sequential study of serum bacterial DNA in patients with advanced cirrhosis and ascites. Hepatology 39:484-491

25. El-Naggar MM, Khalil ESAM, El-Daker MAM, Salama MF (2008) Bacterial DNA and its consequences in patients with cirrhosis and culture-negative, non-neutrocytic ascites. J Med Microbiol 57:1533-1538

26. Christensen JE, Reynolds CE, Shukla SK, Reed KD (2004) Rapid molecular diagnosis of lactobacillus bacteremia by terminal restriction fragment length polymorphism analysis of the $16 \mathrm{~S}$ rRNA gene. Clin Med Res 2:37-45

27. Dicksved J, Lindberg M, Rosenquist M, Enroth H, Jansson JK, Engstrand L (2009) Molecular characterization of the stomach microbiota in patients with gastric cancer and in controls. J Med Microbiol 58:509-516

28. Justesen US, Holt HM, Thiesson HC, Blom J, Nielsen XC, Dargis R, Kemp M, Christensen JJ (2007) Report of the first human case of Caulobacter sp. infection. J Clin Microbiol 45: 1366-1369

29. Runyon BA (1990) Monomicrobial nonneutrocytic bacterascites: a variant of spontaneous bacterial peritonitis. Hepatology 12:710 715

30. Rimola A, Salmerón JM, Clemente G, Rodrigo L, Obrador A, Miranda ML, Guarner C, Planas R, Solá R, Vargas V (1995) Two different dosages of cefotaxime in the treatment of spontaneous bacterial peritonitis in cirrhosis: results of a prospective, randomized, multicenter study. Hepatology 21:674-679

31. Toledo C, Salmerón JM, Rimola A, Navasa M, Arroyo V, Llach J, Ginès A, Ginès P, Rodés J (1993) Spontaneous bacterial peritonitis in cirrhosis: predictive factors of infection resolution and survival in patients treated with cefotaxime. Hepatology $17: 251-257$ 